UDK 630*1:502.175(497.11)“2019““

Original scientific paper

\title{
FOREST VITALITY (ICP LEVEL I AND SAMPLE PLOT LEVEL II-CRNI VRH AND MOKRA GORA) WITH A SPECIAL EMPHASIS ON ABIOTIC AGENTS IN THE REPUBLIC OF SERBIA IN 2019
}

\author{
Renata GAGIĆ-SERDAR ${ }^{l}$, Tomislav STEFANOVIĆ ${ }^{l}$, Ilija ĐORĐEVIĆ , \\ Goran $\check{C} E \check{S} L J A R^{l}$, Natalija MOMIROVIĆ ${ }^{l}$
}

\begin{abstract}
The vitality of forests depends on environmental conditions and a great number of abiotic factors, such as climatic characteristics, atmospheric deposition, forest fires, direct atmospheric impacts. Nevertheless, abiotic agents are group of the most important factor threatening the trees sampled and monitored for more than a decade and a half in continuity. Therefore, further analysis can provide different trends of their direct effects and degrees of their out-turn. International program for further and more detailed monitoring of the forest condition in the Republic of Serbia (ICP Forests), which is carried out on both Level I and Level II(Mokra Gora and Crni Vrh) sample plots, will enable scientists to determine the vitality of forests both at the local and at the regional level. Results are vitality and health state of the forest ecosistems with emphasis on abiotic factors.
\end{abstract}

Key words: abiotic impacts, monitoring, state crown, Serbia

\section{ВИТАЛНОСТ ШУМА (ІСР НИВО І И НИВО ІІ -ЦРНИ ВРХ И МОКРА ГОРА) СА ПОСЕБНИМ ОСВРТОМ НА АБИОТИЧКЕ АГЕНСЕ У РЕПУБЛИЦИ СРБИЈИ У 2019. ГОДИНИ}

Сажетак: Виталност иума зависи од услова животне средине и великог броја абиотских фактора, попут климатских карактеристика, атмосферских талога, шумских пожара, директних атмосферских утицаја... (Невенић et al., 2008b). Ипак, абиотски узрочнищи су најзначајнија група фактора који угрожавају

\footnotetext{
${ }^{1}$ Institute of forestry, Knaza Višeslava 3, 11000 Belgrade

Author of correspondence: Renata Gagić-Serdar Institute of forestry, Knaza Višeslava 3, 11000 Belgrade

e-mail:katas96@hotmail.com; serdarrenata79@gmail.com
} 
стабла, која се у континуитету прате више од деценије и по. Стога, даљьа анализа може пружити различите трендове юихових директних ефеката и различито интерпретиране резултате. Међународни програм за даље и деталније праћење стана шума у Републищи Србији (ICP Forests, ICP за шуме), који се спроводи на огледним париелама Нивоа I и II, омогућиће научнищима да одреде вредност виталности шума како на локалном тако и на регионалном нивоу.

Кључне речи: абиотички утицаји, мониторинг, стање круна, Србија

\section{INTRODUCTION}

Forests decay is reflected in the impaired vitality of the trees and it is a consequence of the adverse effect of the abiotic and biotic factor originated. Complex of factors effects on the trees as living organisms and complex natural processes within forest biocenoses. Agents classified in one of these two groups may act simultaneously or alternate successively. Groups whose participation is one of those with special high risk for the health of forests are emphasized this time meaning abiotic factors group. Some occur along with biotic and are occurrences of both group chained action causes frequent beech disease, the most numerous species at Sample plot LEVEL 1, and Sample plot LEVEL 2 in locality Mokra Gora and Crni vrh). Identifying processes in forest ecosystems requires detailed research into the environmental factors that can be obtained as an identifier. These are, first of all, climate change, then determining the condition of the canopies that are subject to their impact, the types of these factors and their whole mechanism of action as important agents that must be kept under control in order to have complete insight into all aspects of their action on forest communities. An insight into the condition of the forests in order to reach conclusions about the necessary improvement measures can be established through monitoring the condition of the forests (MANUAL, 2010):. The subject matter of ICP Forests is the monitoring of anthropogenic (primarily air pollution) and all (here) abiotic adverse factors on the condition and development of Europe's forest ecosystems (Google 1). Under the coordination of the Forest Administration and the NFC - the National Focal Point of the Republic of Serbia for forest monitoring at the Institute of Forestry in Belgrade, the forest monitoring system is integrated into the state forestry environment, so that several institutions with their associates participate in the program (Zúbrik et al. 2008).

\section{RESEARCH AREA, METHOD AND CRITERIA}

Forest condition monitoring is one of the largest forest bio-monitoring systems that is implemented in order to detect changes in forests using key ecological parameters. On the basis of the obtained data, it is possible to determine spatial and temporal trends in the state of forests, i.e., tree species and their crown condition by region. A wider context can include the correlation of the crown condition data with the data obtained from corresponding sample plots as well as external data on natural and human stress factors, which all provide some 
indications of the interrelations between the forest vitality and stress factors (Nevenić et al. 2014).

In the period from 2002 to 2019 , a total of 130 sample plots arranged in 16 $\mathrm{x} 16 \mathrm{~km}$ and $4 \mathrm{x} 4 \mathrm{~km}$ grids have been established in the territory of the Republic of Serbia. (Nevenić et al., 2006). In 2019, the condition of forest species was assessed on all 130 sample plots in Serbia.

Institute of Forestry teams conducted field visits of sample plots in the area of forest estates in the presence of experts, forest inspectors, forest engineers and technicians responsible for the particular sample plot localities or areas.

Visual monitoring, conducted according to the ICP Forests Manual, was carried out on the sample plots in the territory of the Republic of Serbia. It included crown condition assessment and determination of damage caused by diseases and pests. According to ICP Forests Manual, crown condition assessments are mandatory on all plots once a year, soil condition assessments every ten years as well as the assessment of the nutritional condition of forest trees - foliar analysis.

A sample plot is determined by its coordinates and its center is marked with a metal rod of a vivid colour. Trees are systematically sampled for the purpose of crown condition assessment. As they are selected in 4-point clusters, it makes a total of 24 trees. In the direction of the 4 cardinal points at a distance of $25 \mathrm{~m}$ from the center, six closest trees are selected for the purpose of crown condition monitoring. Tree samples include all tree species with a minimum height of $60 \mathrm{~cm}$. The crown canopy classes after $\mathrm{Kraft}^{2}$ (dominant, co-dominant, subdominant, suppressed and dying), are used as a criterion for selecting trees, excluding trees with significant mechanical injury. The selected trees are permanently marked with numbers for the future continuous assessments. The trees which are removed due to management measures or for some other reasons are replaced with new ones. If a stand is clear-felled, the central point is kept until the establishment of a new stand (Google 2).

Within the framework of national and transnational research (Level I), the crown condition is assessed by the classes of defoliation, discolouration and combined damage classes. Defoliation is assessed in 5\% intervals and it is classified into 5 groups of uneven range (Table 1).

Table 1. Classes of defoliation according to UN/ECE and $^{\text {EU }}{ }^{4}$ classification
\begin{tabular}{|c|c|c|}
\hline $\begin{array}{c}\text { Classes of defoliation - } \\
\text { dieback }\end{array}$ & $\begin{array}{c}\text { Degree of } \\
\text { defoliation }\end{array}$ & Leaf loss (\%) \\
\hline 0 & No & $0-10$ \\
\hline 1 & Slight & $10-25$ \\
\hline 2 & Moderate & $25-60$ \\
\hline 3 & Severe & $60-100$ \\
\hline 4 & Dead & 100 \\
\hline
\end{tabular}

\footnotetext{
${ }^{2}$ The modified concept of the crown canopy classification, the traditional measurement of variables used in forestry, first applied by Kraft, in Germany, in the nineteenth century, (1884)

${ }^{3}$ United Nations Economic Commission for Europe

${ }^{4}$ European Union
} 
Abiotic factors are also included because, although they are primary agents, they give rise to secondary damage agents and make it easier for insects and fungi to infest once healthy trees. These are the reasons we have been sampling and monitoring trees all these years trying to put all pieces together and get the whole picture.

\section{RESULTS ON THE HEALTH CONDITION OF TREES ON LEVEL I TOGETHER WITH LEVEL II (CRNI VRH) AND (MOKRA GORA) SAMPLE PLOTS IN 2019}

\subsection{MONITORING PLOT ON LEVEL II (CRNI VRH)}

During 2019 at LEVEL II, trees were observed on 130 Sample plots of Level one Sample plot LEVEL 2 in localities (Mokra Gora and Crni vrh).

It was found that one tree was completely taken down from the roots and one tree was dried. Among other observations, it is important to note that the defoliation of beech trees during the late summer inspection was drastically lower than during the spring 2019 inspection, with more trees re-leafing, mainly in tufts. icebreakers. One tree is present with bark inflammation, and many tree branches still have branch breaks and rot that develops at the sites of injury. From the phytopathological damage, the presence of the fungus Nectria coccinea, which together with the insect Cryptococcus fagisuga, causes a dangerous "beech bark disease" in two trees (76 and 87). Also there were found were rot on branches and knots (trees 62, 65, 67, 72, 73, 96 and 100) and central rot on trunks (tree 90).

\subsection{MONITORING PLOT ON LEVEL II (MOKRA GORA)}

Inspection of health state for Level II Sample plot Mokra Gora is Dedicated with 32 white pine trees in subparcel 2, trees from 82-407.

This year, 2019, during one of the major summer storms, lightning struck in one of trees on Mokra Gora exactly on the plot itself. The fire spread to more than a dozen surrounding trees, but there was no total destruction, ie. only surface (burk) was that fire left a mark on. It was observed that it shortened from a lower angle in terms of terrain to higher positions, and that at a certain height it also stopped spontaneously within the samle plot area. Still, the fire has affected the trees significantly but the extent of the damage has yet to be evaluated.

\subsection{SAMPLE PLOTS LEVEL I}

Inspection of health state for Level I Sample plot was performrd on 130 sample plots with emphasis on damages of abiotic origin. Those are, among other things, bulge of non-parasitic origin and occur on the bark of beech trunks, on individual trees (Češljar et al. 2014). Frostbites are noticeable, almost the entire length of the trunk. In 2019, precipitation was very high, especially in the first part of the growing season. They were not absent during the rainy summer, and this year, which was extremely and very humid, resulted in the end of normalized drying, but due to the extremely high humidity, this factor was compounded with 
fungi, which result in noticeable yellow-chlorotic spots, so the trees ended the season with chlorotic crowns, as if the fall had started earlier in August, even though the leaves remained on the branches.

Table 2. Damage causes on aple plot Level I trees in 2019

\begin{tabular}{|c|c|c|c|c|c|c|c|c|}
\hline $\begin{array}{l}\text { Врсте } \\
\text { дрвета/ } \\
\text { Tree } \\
\text { species } \\
\end{array}$ & $\begin{array}{l}\text { Инсект/ } \\
\text { Insects }\end{array}$ & $\begin{array}{c}\text { Гљиве/ } \\
\text { Fungi }\end{array}$ & $\begin{array}{l}\text { Абиотички } \\
\text { агенси/ } \\
\text { Abiotic } \\
\text { agents } \\
\end{array}$ & $\begin{array}{l}\text { Човек/ } \\
\text { Human }\end{array}$ & $\begin{array}{l}\text { Baтpa/ } \\
\text { Fire }\end{array}$ & $\begin{array}{c}\text { Локално } \\
\text { загађење/Local } \\
\text { pollution }\end{array}$ & $\begin{array}{c}\text { Остале } \\
\text { штете/ } \\
\text { Other } \\
\text { damage }\end{array}$ & $\begin{array}{c}\text { Укупно } \\
\text { оштећено/ } \\
\text { Total } \\
\text { damage }\end{array}$ \\
\hline $\begin{array}{l}\text { Све врсте/ } \\
\text { All species }\end{array}$ & 12,0 & 7,7 & 1,2 & 0,8 & 0,4 & 0,0 & 9,7 & 31,8 \\
\hline $\begin{array}{l}\text { Лишћари/ } \\
\text { Broadleaves }\end{array}$ & 13,4 & 8,5 & 1,3 & 0,9 & 0,5 & 0,0 & 8,7 & 33,3 \\
\hline $\begin{array}{l}\text { Четинари } \\
\text { Conifers }\end{array}$ & 1,4 & 1,7 & 0,0 & 0,0 & 0,0 & 0,0 & 16,8 & 19,9 \\
\hline $\begin{array}{l}\text { Буква/ } \\
\text { Beech }\end{array}$ & 27,7 & 11,6 & 2,4 & 2,2 & 0,6 & 0,0 & 11,9 & 56,4 \\
\hline $\begin{array}{l}\text { Китњак/ } \\
\text { Sessile oak }\end{array}$ & 4,5 & 5,0 & 0,5 & 0,0 & 0,0 & 0,0 & 9,0 & 19,0 \\
\hline $\begin{array}{l}\text { Цеp/ } \\
\text { Turkey oak }\end{array}$ & 10,9 & 6,7 & 2,0 & 0,7 & 0,6 & 0,0 & 6,7 & 27,6 \\
\hline $\begin{array}{l}\text { Jeла/ } \\
\text { Fir } \\
\end{array}$ & 0,0 & 2,9 & 0,0 & 0,0 & 0,0 & 0,0 & 7,4 & 10,3 \\
\hline $\begin{array}{l}\text { Смрча/ } \\
\text { Norway } \\
\text { spruce }\end{array}$ & 3,5 & 0,0 & 0,0 & 0,0 & 0,0 & 0,0 & 37,8 & 41,3 \\
\hline $\begin{array}{l}\text { Црни бор/ } \\
\text { Austrian } \\
\text { pine }\end{array}$ & 0 & 0 & 0 & 0 & 0 & 0 & 0 & 0 \\
\hline
\end{tabular}

Table 3. Abiotic Damage causes, host plant tree species and sample plots with those

\begin{tabular}{|c|c|c|c|c|c|c|}
\hline $\begin{array}{l}\text { Damage / Tree } \\
\text { species / } \\
\text { Sample plot / } \\
\text { Cause }\end{array}$ & $\begin{array}{l}\text { Abiotic agents } \\
\text { ice ruptures, }\end{array}$ & $\begin{array}{c}\text { Frost/ and bark } \\
\text { cracks }\end{array}$ & $\begin{array}{l}\text { Drought /sample } \\
\text { plot number }\end{array}$ & $\begin{array}{c}\text { Man-made } \\
\text { mechanical } \\
\text { damage from } \\
\text { pullout force } \\
\text { (bark stripped } \\
\text { off, breakage, } \\
\text { various injuries) } \\
\text { / sample plot } \\
\text { number }\end{array}$ & $\begin{array}{l}\text { Forest fires } \\
\text { / sample } \\
\text { plot number }\end{array}$ & $\begin{array}{c}\text { Other } \\
\text { causes / } \\
\text { sample } \\
\text { plot } \\
\text { number }\end{array}$ \\
\hline Beech & 32 & $\begin{array}{c}\text { Several causes } \\
\text { combined / } 9,13, \\
50,52,55,58,85, \\
91,98,99,87, \\
407,412\end{array}$ & 412,413 & $\begin{array}{c}\text { Mechanical } \\
\text { injury / 4, 50; } \\
\text { severe } \\
\text { mechanical } \\
\text { injury / 51, 69, } \\
90 \\
\end{array}$ & 96 & \\
\hline Hornbeam & & 55 & & & & \\
\hline Turkey oak & $\begin{array}{c}29,34,36 \\
39\end{array}$ & & $\begin{array}{c}\text { Several causes } \\
\text { combined / } \\
6,70,92\end{array}$ & & & $\begin{array}{c}\text { Non } \\
\text { parasitic } \\
\text { Bulge /30 } \\
38 \\
\end{array}$ \\
\hline Hungarian oak & $\begin{array}{c}2,17,2029,39 \\
\text { and } 88\end{array}$ & Frost ribs / 17, 20 & 17,20 & & & 60 \\
\hline
\end{tabular}




\begin{tabular}{|c|c|c|c|c|c|c|}
\hline $\begin{array}{c}\text { Damage / Tree } \\
\text { species / } \\
\text { Sample plot / } \\
\text { Cause }\end{array}$ & $\begin{array}{c}\text { Abiotic agents } \\
\text { ice ruptures, }\end{array}$ & $\begin{array}{c}\text { Frost/ and bark } \\
\text { cracks }\end{array}$ & $\begin{array}{c}\text { Man-made } \\
\text { Drought /sample } \\
\text { plot number } \\
\text { damage from } \\
\text { pullout force } \\
\text { bark stripped } \\
\text { off, breakage, } \\
\text { various injuries } \\
\text { / sample plot } \\
\text { number }\end{array}$ & $\begin{array}{c}\text { Forest fires } \\
\text { / sample } \\
\text { plot number }\end{array}$ & $\begin{array}{c}\text { Other } \\
\text { causes / } \\
\text { sample } \\
\text { plot } \\
\text { number }\end{array}$ \\
\hline Sessile oak & 75,77 & 107 & $\begin{array}{c}\text { Severe drought / } \\
78\end{array}$ & & \\
\hline Fir & 418 & $\begin{array}{c}\text { Severe drought / } \\
428,429\end{array}$ & $\begin{array}{c}\text { Mechanical } \\
\text { pullout injury / } \\
401,402\end{array}$ & & \\
\hline Spruce & 73,74 & $/ 419$ & $\begin{array}{c}\text { Mechanical } \\
\text { pullout injury / } \\
406\end{array}$ & & \\
\hline Austrian pine & 419 & 65 & & & & \\
\hline Black locust & 428 & & & & & \\
\hline Scots pine & 45,59 & 53 & & & & \\
\hline
\end{tabular}

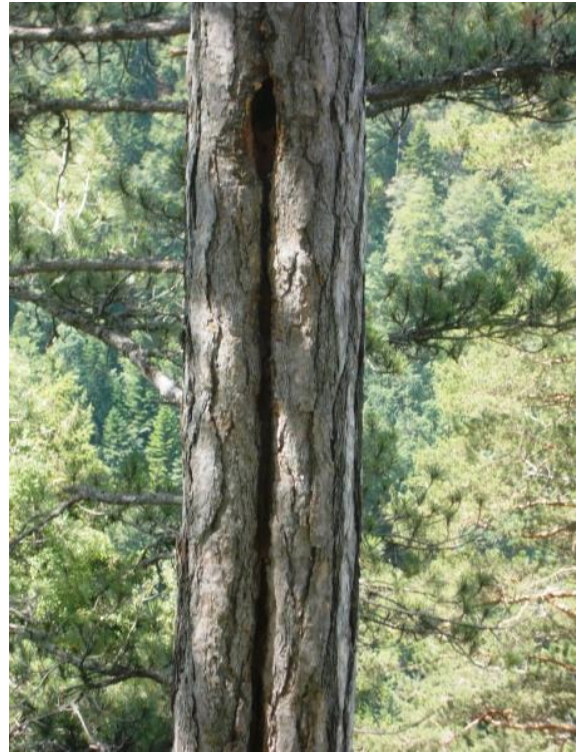

Слика 1. Figure 1. Black pine tree frostbite, SP 53 (Orig.)

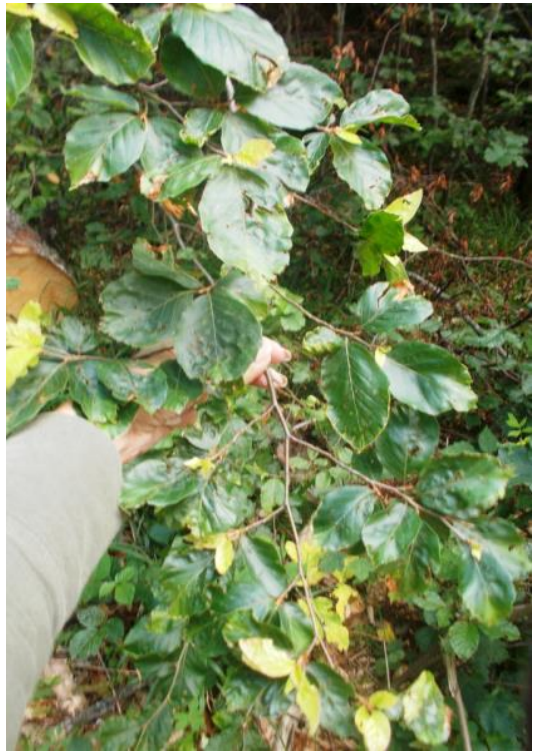

Слика 2. Figure 2. Late frost damage, beech SP 32 (Orig.)

\section{DISCUSSION}

Abiotic damages recorded included bulges of other than parasitic origin in the bark of individual beech trees (Gagić-Serdar et al. 2018). Frost cracks were clearly visible along the entire trunks. In 2019 there was hufe amount of 
precipitation from the beginning of summer and in this rather wet year trees do not displayed yellow chlorotic crowns prematurely, as if the autumn drying commence doesn't apaer, although the leaves remained on branches.

Beech trees at sample plot 7 showed damage and injury from tree cutting and pull-out. In this plot entire quadrants were missing, while some trees had injuries of unknown origin and about ten trees had bark inflammation (Chira, D., F. Chira, 1998). Mechanical damages caused by birds were detected in spruce trees at sample plot 420. Some Turkey oak trees suffered bark damage during tree marking. Man-made mechanical damages were identified in in about ten oak trees per sample plot, resulting from tree cutting and pull out. Such injuries pose a risk of entry of numerous hazardous insects and fungi, which can cause severe diseases. The share of such trees in the total number of trees assessed is $0.62 \%$.

Bulges of non-parasitic origin were detected in beech tree bark at sample plots 30 and 96. Frost cracks stretched along the entire beech tree trunks. In one fir tree a lightning scar stretched along the entire trunk. Mechanical damages to sessile oak tree peaks were recorded in $4 \%$ of trees. Such damages occurred during tree cutting and pull-out. Frost cracks and other mechanical damages were present in Hungarian oak trees as well at 3 sample plots.

In a number of fir trees abundant sap secretion was observed and, according to the historical experience, all such trees are likely to dry the following year. A large-scale presence of lichen Usnea barbata, reflecting a healthy habitat, was perceived. There were also completely dry and broken trees fully covered with lichen (sample plots 415 and 416).

It is important to underline that in 2019 specific old symptoms of an intense and widely spread phenomenon - ice ruptures - were clearly recognized and frequently observed in high, primarily beech forests (Marković et al. 2014). Such quantitatively and qualitatively severe injuries of trees occurred during dormancy in winter 2014/2015, in periods of bitter frost preceded by precipitation or merely high humidity at certain altitudes of Homolje Mountain Range (Marković \& Marković, 2018). Geographically, eastern parts of the country were most affected (sample plots in Eastern Serbia, exceptionally sample plot 70 Lukovo, sample plot 412 Tisovac and and sample plot 413 Jasenova glava). Continuous and mandatory performed sanitation must commence with sanitation tree cutting and further growth measures for a number of reasons. The injured trees are an easy prey for secondary pests and diseases. It is necessary to prevent them, i.e., to eliminate favorable conditions for incidence of possible pest calamities. Wherever an opening appeared, it is necessary to protect the exposed layers (risk of bark inflammation) and put an end as soon as possible to complex yet possible scenarios of cycles of linked and chained damages (an exemplary pattern of a beech stand decay after initial ice rupture as an abiotic factor is presented in Graph 1): 

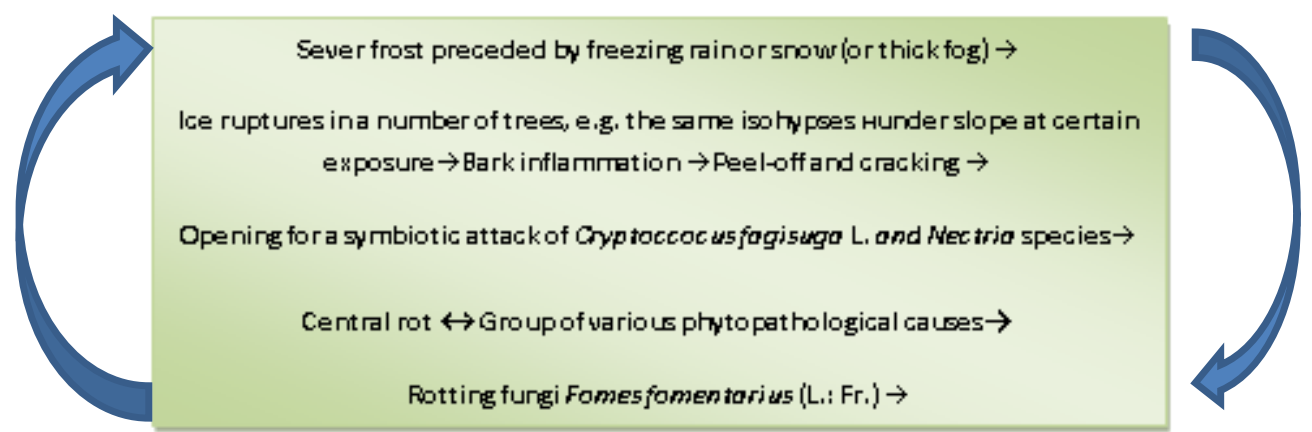

Graph 1. Example of the pattern of beech stand decay after the initial effect of a harmful agent (ice rupture) as an abiotic factor

In 2019 forest fires broke out ( $0.24 \%$ trees affected) at several sample plots (e.g. sample plot 96), which resulted in total absence of assimilation organs in trees. Thereafter, the fire bed is occupied by pioneer vegetation, and more successful in succession are either invasive (blackberry) or economically and productively low graded species (birch, aspen, etc.). Still blazing forest fire in Stara Planina will have far-reaching consequences, but now it's too early for any forecasts or damage assessmant. What is certain is that the contribution on the fire occurrence was the climate factor, and an unusually long and warm period without precipitation precipitation In October of the current year. This year there was a spontaneous fire caused by lightning strikes on the very samle field of Mokra Gora. The fire has affected dozens of trees and the extent of the damage has yet to be assessed (Pictures 3 and 4).

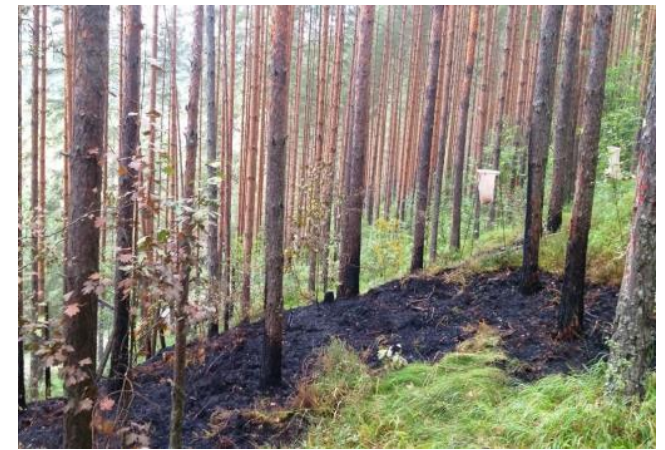

Слика 3. Forest fire on Sample plot Mokra Gora, 2019 (Orig.)

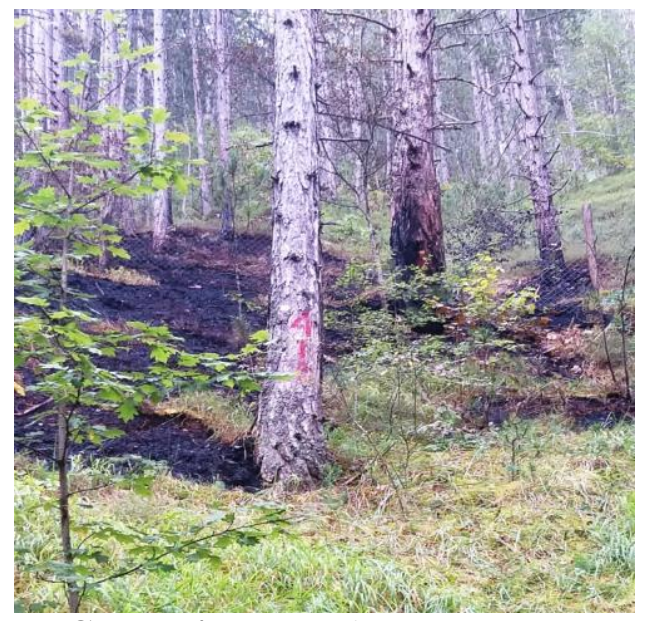

Слика 4. Damged trees from fire caused by lighthing on Sample plot Mokra Gora, 2019 (Orig.)

Abiotic factors included frost shake on the bark of Hungarian oak trees, which were present on a small scale, while the damage to the leaves was very pronounced. Mechanical damage to oak trees was registered in more than $25 \%$ of 
the studied trees and they were caused by human factor, i.e. during tree felling and hauling (Marković et al. 2012). Češljar These injuries pose a potential danger and make trees prone to many harmful insects, disease-causing fungi, as well as wooddestroying organisms (Vajda, 1974).

\section{CONCLUSION}

During 2019, monitoring of the abiotic parameter was carried out at the existing sample plots of Level I and Level II, with the continuously and annually carried out frequency.

At Sample plot Level II Crni Vrh the percentage of trees not affected by defoliation, trees affected by low defoliation and dead trees compared to the previous year was the same.

From the phytopathological damages, the presence of fungus Nectria coccinea was found in two trees. Also observed were rot on branches and nodes (on 7 trees) and central trunk rot (on 1 tree). Although not abiotic these symptoms are an indirect consequence of ice-breaks as a significant factor from the abiotic group.

Defoliation in 2019 at the Sample plot of Level II in Mokra Gora for trees affected by fire may have been the result of a fire extinguished by chance. In general, in 2019, as in the previous year, the damage caused by abiotic factors is the least affected trees on Sample plot Level II Mokra Gora.

The Input entry of new data into the GIS system of NFC Serbia is done every year, which will be a very valuable archive for future scientific research. The more time passes, the better and easier it will be to gain an insight into the state of forests in the experimental fields, the aforementioned influence of abiotic factors and a more accurate approach to the perennial analyzes of the vitality of the forests of the Republic of Serbia.

* ACKNOWLEDGEMENTS: The study was carried out within the Projects:

1. Assessment and monitoring of the impact of air pollution and its effects on the forest ecosystems in the Republic of Serbia without AP Vojvodina in 2019 (Level 1) and implementing intensive monitoring (Level 2) at locations which are located in the area of PE "Kopaonik" Management Unit "Samokovska Reka", Srbijašume, PE "Uzice" Management Unit "Mokra Gora - Panjak", PE "Timocke Sume" Boljevac, Management Unit "Crni Vrh", financed by the Directorate of Forests, Ministry for Agriculture and Environment Protection of the Republic of Serbia, and

2. Project TP-31070: "The Development of Technological Methods in Forestry in order to Attain Optimal Forest Cover", financed by the Ministry of Education and Science of the Republic of Serbia. (Translation: Dragana Popović)

\section{REFERENCES}

Вајда, 3. (1974): Наука о заштити шума, Уџбеник, Загреб, Школска књига

Gagić-Serdar, R., Stefanović, T., Đorđević, I., Češljar, G., Marković, M. (2018): “Forest Vitality (ICP Level I Sample Plots) with a special Emphasis on Biotic Agents in the 
Republic of Serbia in 2018", Sustainable Forestry, pp. 55-66, Vol. 77-78, ISSN 1821-1046 UDK 630 COBISS.SR-ID 157148172 Publisher: Institute of Forestry, Belgrade, Serbia http://www.forest.org.rs

Češljar G., Nevenić, R., Bilibajkić S., Stefanović T., Renata Gagić-Serdar R., Đorđević I., Marković M, Rajković S, Nevenić, R. (2014): The Most Frequent Agents Of Damages Of Trees At The Sample Plots In Serbia: SUSTAINABLE FORESTRY COLLECTION TOM 69-70, Institute Of Forestry, Belgrade, pp 85-94

Marković M., Rajković S., Rajković, R. (2012): “Analysis of the impact of injuries caused by the influence of mechanical and abiotic factors on the occurrence of harmful fungal organisms", Sustainable Forestry, Vol. 65-66, pp. 97-102, ISSN 1821-1046, UDK 630, Publisher: Institute of Forestry, Belgrade, Serbia http://www.forest.org.rs

Marković M., Rajković S., Nevenić, R. (2014): The Most Frequent Agents Of Damage Of Trees On The Sample Plots In Serbia: Sustainable Forestry, Collection of Papers 69-70, Institute of Forestry, Belgrade, pp. 85-94

http://www.forest.org.rs

Marković, N., Marković, M. (2018): "Disastrous Ice Breaks in Eastern Serbia - GIS Analysis of their Relationship with Orographic Characteristics", Sustainable Forestry, pp. 67-76, Vol. 77-78, ISSN 1821-1046 UDK 630 COBISS.SR-ID 157148172 Publisher: Institute of Forestry, Belgrade, Serbia http://www.forest.org.rs

Nevenić R., Tabaković-Tošić M., Rajković S., Rakonjac Lj., Miletić Z., Marković M., Bilibajkić S., Stefanović T., Stajić S., Čokeša V., Radulović Z., Poduška Z., Gagić-Serdar R., Đorđević I., Češljar G., (2014): Procena i praćenje efekata-uticaja vazdušnih zagađenja na šumske ekosisteme u Republici Srbiji. Nivo I i Nivo II. (Poglavlje 4, 5, 6, 7, 9, 10, 13, 16) ISBN 987-86-80439-35-8

Zúbrik, M., Kunca, A., Novotný, J. (2008): Hmyz Huby, Atlas poškodeni lesných drevin, Institutum Forestale Zvolen

***** (2010): MANUAL on methods and criteria for harmonized sampling, assessment, monitoring and analysis of the effects of air pollution on forests. United Nations Economic Commisions for Europe. Convention on Long-range Tran boundary Air Pollution.International Co-operative Programme on Assessment and Monitoring of Air Pollution Effects on Forests (ICP Forests). Programme Coordinating Centre of ICP Forests. Johann Heinrich von Thunen-Institute. Institute for World Forestry, Hamburg, Germany. ISBN 978-3926301-01-1. www.icp-forests.org/Manual.htm

***** (2010a): Manual on methods and criteria for harmonized sampling, assessment, monitoring and analysis of the effects of air pollution on forests - Parts I, II, IX, V, VII, VIII, IX, XVII; ISBN 978-3-926301-01-1, Edited in 2010

***** (2010d): Europe`s Forests 1985-2010. 25 Years of Monitoring Forest Condition by ICP Forests. Hohann Heinrich von Thuunen - Institute, Institute for World Forestry. PCC of ICP Forests, Hamburg, Germany. 
***** Forms and Explanatary Items To be applied for data submission 2013 onwards Version n8 Last upadate: 16 May 2013. http://www.icp-forests.org/page/data-submission

Google 1 - http://www.icp-forests.org/Manual.htm

Google 2 - http://www.icp-forests.org/

\title{
FOREST VITALITY (ICP LEVEL I AND SAMPLE PLOT LEVEL II-CRNI VRH AND MOKRA GORA) WITH A SPECIAL EMPHASIS ON ABIOTIC AGENTS IN THE REPUBLIC OF SERBIA IN 2019
}

\author{
Renata GAGIĆ-SERDAR, Tomislav STEFANOVIĆ, Ilija ĐORĐEVIĆ, \\ Goran $\check{C} E \check{S} L J A R$, Natalija MOMIROVIĆ
}

\section{Summary}

The estimation of the crown condition, through data values for defoliation and chlorosis, and the establishment of damage contributes to the performance of definitive conclusions about the adverse effect of complex abiotic factors. This paper are focused on abiotic, those chainedwith them, their nature and it's violation of the vitality of forests in 2019 Serbia.

Direct impact of these factors, conditions trees state and can be taken as a result of forest communities health, reversebly. Primarily because of the short time period processed. Problem concerning the interpretation of results and their occasional fluctuations, highlights the importance of continuous monitoring of parametars as well as additional evaluation of various abiotic and environmental data et the end.

\section{ВИТАЛНОСТ ШУМА (ІСР НИВО І И НИВО ІІ -ЦРНИ ВРХ И МОКРА ГОРА) СА ПОСЕБНИМ ОСВРТОМ НА АБИОТИЧКЕ АГЕНСЕ У РЕПУБЛИЦИ СРБИЈИ У 2019. ГОДИНИ}

\author{
Рената ГАГИЋ-СЕРДАР, Томислав СТЕФАНОВИЋ, Илија БОРЂЕВИћ, \\ Горан ЧЕШљАР, Наталија МОМИРОВИЋ
}

\section{Резиме}

Процена стања круна, кроз вредности података за дефолијацију и хлорозу, и процену оштећења доприноси извођењу коначних закључака о штетном утицају сложених, овде, абиотских фактора. Овај рад је фокусиран на абиотичке, као и оне везане за њих, њихову природу и нарушавање виталности шума из разлога деловања истих у 2019. години у Србији.

Директан утицај ових фактора, утиче на здравствено стање стабала на БИТ, оба Нивоа и може се тумачити као резултат општег стања шумских заједница, и обратно њихово деловање на те факторе. Првенствено због кратког временског периода који се обрађује, 2019. година. Проблем који се односи на интерпретацију резултата и њихове повремене флуктуације, наглашава важност континуираног праћења параметара, као и додатну процену различитих абиотичких чинилаца, података о животној средини и тако циклично. 